Bulletin of Prarmaceutical Sciences
Assiut University
Website: http://lbpsa.journals.ekb.eg/
e-mail: bullpharm@aun.edu.eg

\title{
ANALYSIS OF COST-OF-ILLNESS DUE TO TYPHOID FEVER IN TERTIARY HEALTH CARE HOSPITALS AND PHARMACEUTICAL EVALUATION OF DIFFERENT BRANDS USED IN THE TREATMENT
}

\author{
Muhammad Azeem ${ }^{1,2}$, Humaira Naureen ${ }^{2}$, Muhammad Iqbal Nasiri ${ }^{1 *}$ and \\ Muhammad Umair Saleem ${ }^{1}$ \\ ${ }^{1}$ Department of Pharmaceutics, Hamdard Institute of Pharmaceutical Sciences, Hamdard \\ University Islamabad Campus, Pakistan \\ ${ }^{2}$ Department of Pharmaceutics, Riphah Institute of Pharmaceutical Sciences, Islamabad, \\ Pakistan
}

\begin{abstract}
The objectives of the current study were to estimate the out-of-pocket costs of illness of blood culture-confirmed typhoid fever, as well as to evaluate the different brands of ciprofloxacin $\mathrm{HCl}$ used in the treatment of typhoid fever. Therefore, a comparative study was designed for the assessment of costs of treatment at sixteen public (Government sector) and private tertiary health care hospitals located in Rawalpindi and Islamabad, Pakistan. On the basis of prescriptions collected from the hospitals, seven different brands of ciprofloxacin $\mathrm{HCl}$ prescribed in the treatment of typhoid fever were purchased from retail pharmacies for quality assessment. The mean costs for fourteen days and seven days treatment were analyzed and the overall costs of treatment were high at private health care sectors than public sectors. Model independent approach like similarity factor $\left(f_{2}\right)$ was also applied to assess the similarity between the dissolution profiles of different brands, and result indicated that three brands were found to be similar with reference product, while, three were dissimilar. It can be concluded that this cost-effective analysis of antibiotics used in the typhoid fever, will help to the local regularity body as well as WHO to update typhoid fever immunization recommendations. Ciprofloxacin was found an effective antibacterial agent in the treatment of typhoid fever and all brands met the pharmaceutical quality parameters. Thus, physicians, pharmacists and patients can select most appropriate quality brand for the therapy of typhoid fever.
\end{abstract}

\section{INTRODUCTION}

Typhoid fever, one of the important public health problems in developing countries, caused by Salmonella enterica serotype typhi (S. typhi $)^{1}$. Crump et al., estimated that there were approximately 21 million typhoid fever cases and 216000 deaths worldwide ${ }^{2}$. In Asia and South Asia, highest incidence rate of typhoid fever was found i.e. more than 100 cases per 100,000 populations occurred each year. Another multicentric study of Asian countries, including China, India, Indonesia, Pakistan and Vietnam, estimated the incidence of typhoid fever ranged from 15.3 per 100,000 persons/year in China to 451.7 per 100,000/year in Pakistan. The rates were significantly higher in Pakistan and India as compare to Vietnam, Indonesia and $\mathrm{China}^{3}$. These high rates of incidence can be reduced by improving sanitary and health care conditions ${ }^{4}$. The treatment of typhoid fever was introduced in 1948 with chloramphenicol ${ }^{5}$. Since, it has been greatly concerned that multidrug resistant (MDR) strains of $S$. typhi showed resistance to the classical first-line anti-typhoid agents (Ampicillin, Chloramphenicol, Co-trimoxazole), which were used in 1980 's ${ }^{6 \& 7}$. For empirical therapy of suspected typhoid fever, fluoroquinolones and third generation cephalosporin have become drugs of choice. Nevertheless, recent reports of reduced

Received in 15/1/2020 \& Accepted in 9/5/2020 
susceptibility to these agents potentially increased the chance of re-emergence of untreatable typhoid fever and an increasing global burden ${ }^{8}$. The definitive diagnosis of typhoid fever depends on the isolation of $S$. typhi organisms from the blood or bone marrow or stool ${ }^{9}$. In developing countries like, Pakistan, the main problem is the irrational prescribing of antibiotics by physicians. Pharmaceutical industries provide incentives to the physicians, which leads to irrational prescribing and ultimately increases the cost of illness. The trend of prescribing multinational company's medicines is another important factor of increasing cost of treatment. Typhoid fever is the most common febrile illnesses encountered by practitioners in developing countries ${ }^{4}$. Ciprofloxacin $\mathrm{HCl}$ is an antibiotic belong to the class, fluoroquinolones. It was first sold by Bayer Pharmaceuticals ${ }^{10}$. Ciprofloxacin $\mathrm{HCl}$ has been prescribed by different practitioners in the therapy of suspected typhoid fever caused by Salmonella typhi. Selection of a safe, effective and economic brand of the same generic is one the key indicator for effective treatment of diseases. Costs of illness can be estimated from private and public points of view. Private cost of illness means the treatment cost tolerated by the patients themselves whereas, public cost of illness means total cost acquired by a healthcare provider, i.e. government ${ }^{11}$. Therefore, in the current study, the costs of illness of typhoid fever at tertiary health care hospitals located at Rawalpindi and Islamabad, Pakistan and different brands of ciprofloxacin $\mathrm{HCl}$ used in the treatment of typhoid fever were estimated.

\section{MATERIAL AND METHODS}

\section{Materials}

Ciprofloxacin reference sample was kindly gifted by Pearl Pharmaceuticals, Islamabad. Acetonitrile (HPLC Grade), triethlyamine, phosphoric acid and all other chemicals were procured from Merck (Darmstadt, Germany). Apparatus utilized for brands analysis were analytical balance (Sartorius, Germany), Tablet hardness tester (Erweka, Germany), Disintegration test apparatus (ED2-SAPO, Electrolab, India), Dissolution test apparatus (USP apparatus II,
Electro Lab TDT 08L),, Friabilator (Erweka, Germany), Sonicator (Isolab, Germany) and Magnetic stirrer (Isolab, Germany). Spectrophotometer (Shimadzu UV-1800) and HPLC (Shimadzu, Tokyo, Japan) with a UV detector (SPD-20A; Tokyo, Japan).

\section{Methods \\ Study design}

A comparative retrospective study was designed with the aimed, to assess the cost of illness, as well as to evaluate, which sectors (public or private) of health care of Pakistan is providing cost effective treatment for typhoid fever. Quantitative method was used for the purpose of data collection so that a cost effective and cost expensive treatment can be estimated.

\section{Study settings, respondents and data sampling}

A retrospective surveys were conducted on tertiary hospitals data located at Islamabad Capital and Rawalpindi, Pakistan. Both the cities feature a humid subtropical climate with long and very hot summers, a monsoon and short mild wet winters. In summer the maximum temperature can sometimes soar up to $46^{\circ} \mathrm{C}$, while, it may drop to minimum of $4^{\circ} \mathrm{C}$ in winter ${ }^{12}$. All the hospitals provides both inpatient and outpatient care. Collected data showed that most patients were treated as outpatients at these hospitals. The sampling unit was the hospital facility and sampling element was prescription. The prescriptions were analyzed and cost of treatment was calculated by determining the cost of antibiotics and antipyretics prescribed. Effect of brand prescribing on the cost of therapy was also assessed. Hospitals were randomly selected on the basis of accessibility to the data and cooperation. Total of sixteen well known hospitals were targeted, eight were public/government and eight were private hospitals. As per WHO standard, sample size of 30 prescriptions from each public and private tertiary health care hospitals were collected (see, Table 2).

\section{Data collection procedure of prescriptions}

The respondents were informed about the study designed. From each public and private sector hospitals, 30 prescriptions were taken, 
thus, a total of 480 prescriptions were collected from 16 hospitals of Rawalpindi and Islamabad ( 8 public and 8 private) as given in Table 2 . Moreover, the combinations of therapy for typhoid were separated and cost of prescription for seven and fourteen days were calculated for each combination. Treatment cost was calculated by calculating individual cost per therapy of antibiotics. Cost of therapy was calculated with the help of PharmaGuide Book $^{13}$.

\section{Data analysis of prescriptions}

After data collection, data was coded and analyzed by using SPSS version 16.0 (Statistical Package for the Social Sciences, used for complex statistical data analysis). Statistical analysis was done via Chi-Square test to find out the differences and association among variables.

\section{Collection and assessments of brands of ciprofloxacin $500 \mathrm{mg}$ tablets}

Seven brands (four local and three multinational) of ciprofloxacin $\mathrm{HCl} 500 \mathrm{mg}$ tablets were collected from retail pharmacies located at Islamabad, Pakistan and they were coded as Cipro-1, Cipro-2, Cipro-3, Cipro-4, Cipro-5, Cipro-6 and Cipro-7. Ciprofloxacin $\mathrm{HCl} 500 \mathrm{mg}$ ) tablets brands were characterized using official ${ }^{14}$ and un-official methods for different pharmaceutical quality parameters such as, weight variation, hardness, friability, disintegration time and assay.

\section{Weight variation test}

Twenty tablets were selected randomly from each brand and individually weighed by using digital balance (Sartorius CP 224S, Germany). Average weight of tablet was calculated and percentage deviation was assessed for each brand. The limit for tablets weighing more than $500 \mathrm{mg}$ was $\pm 5 \%$.

\section{Hardness test}

Sufficient strength are required to avoid breaking during handling, coating, filling and transportation. Limit for tablet hardness was set in between $5-10 \mathrm{~kg} / \mathrm{cm}^{2}$ and tablets were checked through hardness tester (Erweka TBH 125, Germany).

\section{Friability test}

The friability test of each brand was performed using friabilator (Erweka, Germany), operated for $4 \mathrm{~min}$ at a speed of 25 rotation/min. Friability test was performed by taking initial and final weight of 10 tablets and calculated by using equation $1^{15}$. The specification given in the USP for friability test is not more than $1 \%$.

$$
\text { Friability }(\%)=\frac{(\text { Initial Weight }- \text { Final Weight })}{\text { Initial Weight }} \times 100
$$

\section{Disintegration test}

Disintegration test was performed by using USP disintegration apparatus (basketrack assembly). Disintegration test was used to assess whether tablet disintegrates completely without any fragments remaining on the mesh of screen of the tubes under the prescribed experimental conditions. For this purpose, six tablets of each brand were placed in each six tubes. The assembly was operated in $0.1 \mathrm{~N} \mathrm{HCl}$ solution maintained at $37^{\circ} \mathrm{C} \pm 2$. The mean disintegration time of each tablets brand was determined. For film coated tablet disintegration time should not be more than 30 $\min ^{16}$.

\section{Drug content analysis}

Ten tablets of ciprofloxacin $\mathrm{HCl}$ were crushed into a uniform powder using mortar and pestle to evaluate for their drug content. It was performed by using HPLC method as stated in the official Pharmacopeia ${ }^{16}$. The standard solution of ciprofloxacin was prepared by mixing $12.5 \mathrm{mg}$ of ciprofloxacin reference standard in $50 \mathrm{~mL}$ volumetric flask containing mobile phase and then, $0.1 \mathrm{~mL}$ of $7 \%$ phosphoric acid was added, mixed and sonicated (Isolab, Germany) for $10 \mathrm{~min}$. Then, $5 \mathrm{~mL}$ of this solution was transferred into another $25 \mathrm{~mL}$ flask to achieve an appropriate dilution of $50 \mu \mathrm{g} / \mathrm{mL}$ and volume was made up with same dilution. Similarly, an amount of $500 \mathrm{mg}$ of the homogenized powder (equivalent to 1 tablet) was accurately weighed, transferred into a $100 \mathrm{~mL}$ volumetric flask and then added $0.2 \mathrm{~mL}$ of $7 \%$ phosphoric acid. Next, $70 \mathrm{~mL}$ of mobile phase was added to flask and sonicated for $15 \mathrm{~min}$. The same diluent was used to make up the volume and then mixed for 30 min using magnetic stirrer 
(Isolab, Germany). Transferred $1 \mathrm{~mL}$ of the above solution into a another $100 \mathrm{~mL}$ volumetric flask and made up volume with the same diluent, mixed and filtered through membrane filter having 0.45 -micron pore size. After filtration, degassed and appropriate dilution to $50 \mu \mathrm{g} / \mathrm{mL}$, the sample was injected into HPLC system (Shimadzu, Tokyo, Japan) consisted of UV detector set at $278 \mathrm{~nm}$. The mobile phase used for analysis was composed of triethlyamine and acetonitrile $(87: 13, \mathrm{v} / \mathrm{v})$. An aliquot of $10 \mu \mathrm{L}$ was injected into the HPLC system with auto-sampler (Shimadzu, Tokyo, Japan) and column temperature maintained at $30 \pm 1^{\circ} \mathrm{C}$. The separation drug was performed with a flow rate of $1.5 \mathrm{~mL} / \mathrm{min}$ and the retention time was observed $9.2 \mathrm{~min}$. The chromatograms and area under curves were recorded and quantity of ciprofloxacin was calculated in $\mathrm{mg}$ for each sample. Ciprofloxacin tablets should contain ciprofloxacin hydrochloride not less than $90 \%$ and not more than $110 \%$ of the labeled amount of ciprofloxacin ${ }^{16}$.

\section{In-vitro drug release studies}

The multiple time dissolution test was performed on all the seven brands of ciprofloxacin tablet using USP dissolution type II (Paddle) apparatus. The paddle was rotated at $50 \mathrm{rpm}$ for $30 \mathrm{~min}$. Six tablets were individually placed in each dissolution vessel containing $900 \mathrm{~mL}$ of $0.1 \mathrm{~N} \mathrm{HCl}$ solution, maintained at $37 \pm 0.5^{\circ} \mathrm{C}$. Aliquot of $5 \mathrm{~mL}$ was withdrawn at different time interval of 5, 10, 20 and $30 \mathrm{~min}$ and replaced with the same quantity of fresh medium. Then, $0.9 \mathrm{~mL}$ of sample was taken and diluted up to $50 \mathrm{~mL}$ with the dissolution medium to obtain a concentration of $10 \mu \mathrm{g} / \mathrm{mL}$. The samples were filtered using filter paper of 0.45 -micron pores size. The percentage released of ciprofloxacin was analyzed using UV spectrophotometer (Shimadzu UV-1800), by measuring the absorbance at $277 \mathrm{~nm}$. USP specification claimed that not less than $80 \%$ of the labeled amount should release in $30 \mathrm{~min}^{16}$.

\section{Release profile comparison}

The comparison was performed by using DD-solver software (An Add-In Program for
Modeling and Comparison of Drug Dissolution Profiles $)^{17}$. The similarity factor $\left(f_{2}\right)$ provides simple interpretation of data to evaluate release profile of different brands as compare to reference (Cipro-1). If the values of $f_{2}$ are within range of $50-100 \%$, it indicates similar profile and if $f_{2}$ values are less than $50 \%$, it indicates that there is no similarity between two dissolution profiles, as explained by Zhang et al. ${ }^{17}$ and Costa and Lobo ${ }^{18}$.

\section{Statistical analysis}

All experiments were performed in triplicates and achieved data was analyzed using SPSS and all experimental data was reported as the means $\pm \mathrm{SD}$. Furthermore, ChiSquare test $(p \leq 0.05)$ was applied to evaluate the variances among the cost of different brands of Ciprofloxacin $\mathrm{HCl}$.

\section{RESULTS AND DISCUSSION}

There are two approaches of cost-ofillness studies i.e. prevalence based or incidence-based approach. The prevalencebased cost-of-illness studies measure the economic burden of a disease in a given period, whereas, the incidence-based approach measures the economic burden from the onset of disease until cure or death. The incidencebased approach was adopted in this study and was analyzed from the provider's perspective ${ }^{19}$. Cost effective treatment regarding typhoid fever is not as much efficient in Pakistan as it should be. The average treatment duration for typhoid fever in case of I.V therapy is five to seven days and for oral treatment is almost two weeks ${ }^{9}$. The cost of therapy should be reasonable especially for lower class individuals so that they can bear it. According to WHO treatment guidelines for the management of typhoid fever (see, Table 1), the sensitive cases of typhoid should be treated with ciprofloxacin or ofloxacin and duration of therapy should be five to seven days. Cases with multidrug resistant species should be treated with cefixime for seven to fourteen days. While, severe illness and quinolone resistant typhoid cases, should be treated with cefotaxime, ceftriaxone and azithromycin for ten to fourteen days ${ }^{9}$. 
Table 1: WHO Guidelines (2011) of antimicrobial therapy for treatment of typhoid fever.

\begin{tabular}{|c|c|c|c|}
\hline Susceptibility & Antibiotics & $\begin{array}{c}\text { Daily Dose } \\
(\mathrm{mg} / \mathrm{kg})\end{array}$ & $\begin{array}{c}\text { Duration of } \\
\text { therapy (Days) }\end{array}$ \\
\hline Fully Sensitive & $\begin{array}{l}\text { Ciprofloxacin } \\
\text { Ofloxacin }\end{array}$ & $\begin{array}{l}15 \\
15\end{array}$ & $5-7$ days \\
\hline Multidrug Resistant & $\begin{array}{l}\text { As above } \\
\text { Cefixime }\end{array}$ & $\begin{array}{c}15 \\
15-20\end{array}$ & $7-14$ \\
\hline Quinolone resistant & $\begin{array}{l}\text { Azithromycin } \\
\text { Rocephin }\end{array}$ & $\begin{array}{c}8-10 \\
75 \\
\end{array}$ & $\begin{array}{c}7 \\
10-14 \\
\end{array}$ \\
\hline Fully Sensitive & $\begin{array}{l}\text { Ciprofloxacin } \\
\text { Ofloxacin }\end{array}$ & $\begin{array}{l}15 \\
15\end{array}$ & $10-14$ \\
\hline Multidrug Resistant & $\begin{array}{l}\text { As above } \\
\text { Cefixime }\end{array}$ & $\begin{array}{c}15 \\
15-20\end{array}$ & $10-14$ \\
\hline Quinolone resistant & $\begin{array}{l}\text { Azithromycin } \\
\text { Rocephin } \\
\text { Cefotaxime }\end{array}$ & $\begin{array}{c}8-10 \\
75 \\
80\end{array}$ & $10-14$ \\
\hline $\begin{array}{l}\text { Alternative Effective } \\
\text { Antibiotics }\end{array}$ & $\begin{array}{l}\text { Chloramphenicol } \\
\text { Amoxicillin } \\
\text { Cotrimoxazole }\end{array}$ & $\begin{array}{c}50-75 \\
75-100 \\
8-40 \\
\end{array}$ & $\begin{array}{c}14-21 \\
14 \\
14\end{array}$ \\
\hline
\end{tabular}

The study was conducted in Islamabad and Rawalpindi targeting both public and private tertiary health care hospitals. Total of 16 hospitals were visited, among them 8 were public and 8 were private hospitals. From each facility 30 prescriptions were collected and assessed for cost effectiveness. Thus, a total of 480 prescriptions were analyzed, i.e. $50 \%$ (240/480) from public sector and $50 \%$ (240/480) from private sector as mentioned in table 2.

Table 3 shows the frequency of antibiotics prescribed in term of percentage in different hospitals such as ciprofloxacin tablet $30.21 \%$ (145/480), Ceftriaxone injection $13.75 \%$ (66/480), Ciprofloxacin + Ceftriaxone $10.83 \%$ $(52 / 480)$, Ciprofloxacin + Cefixime $9.79 \%$ (47/480) and Clarithromycin + Amoxicillin \& Clavulanic acid 10\% (48/480). However, the least prescribed antibiotics were Cefixime $(1.25 \%)$ and Levofloxacin (1.25\%), i.e. (6/480). Previously, different researchers estimated the costs of unspecified diarrheal disease $^{20}$ and also estimated the aggregate costs of typhoid fever based on public health surveillance and hospital-based data ${ }^{21}$.

\section{Cost analysis of antibiotics prescribed in different public and private sector hospitals}

Treatment cost for this study was achieved by multiplying the unit costs of all brands used.
These costs were converted into US dollar (\$) in 2014 rate (0.0098 USD $=1$ PKR). The total costs ranges of different brands of antibiotics with generic names and their percentages are given in table 4 . The results showed that the costs of $29.2 \%(140 / 480)$ of brands (Leflox, Novidat, Curitol, Tarivid, Ciprin, Cipval) prescribed by physicians for the treatment of typhoid fever were found in the range $\$ 0.98-$ 9.80 (PKR 100 - 1000). The costs of 30\% (144/480) brands (Cefspan, Cycin, Cefepime + Cefim, Tanzo + Ciproxcin, Tazocin + Novidat, Ciproxcin + Amoxcil, Ciproxcin, Oxidil + Cefim, Cefim + Novidat, Rocephin + Novidat, Axcin, Novidat, Ciproxcin + Cefim, Claritek) were ranged between $\$ 9.81-19.60$ (PKR 1001 to 2000). Similarly, cost of illness of $8.3 \%$ (40/480) brands felt in between $\$ 19.61-\$ 29.40$ (PKR 2001 - 3000). While, 7.3\% (35/480) brands (Cefspan + Klaricid, Cefim + Injection Novidat, Injection Oxidil + Cefim) found in the range of $\$ 29.41-39.20$ (PK R 3001 to 4000). The cost of $3.5 \%(17 / 480)$ antibiotics brands (Injection Cefepime + Cefim, Injection Salxone) were found in the range of \$49.0158.80 (PKR 5001 to 6000). The costs of $8.3 \%$ (40/480) brands (Inj. Rocephin + cefixime, Inj. Rocephin, Inj. Rocephin+ Novidat) felt between \$58.81- 68.60 (PKR 6001 to 7000). The brands (Inj. Rocephin $2 \mathrm{~g}+$ Inj. Rocephin 1g, Inj. Rocephin $2 \mathrm{~g}$, Inj. Rocephin $1 \mathrm{~g}+$ Inj. 
Table 2: List of all public and private hospitals with number of prescriptions collected $(n=480)$.

\begin{tabular}{|c|c|c|c|c|}
\hline \multirow{2}{*}{ S. No. } & \multicolumn{2}{|c|}{ Name of hospitals } & \multirow{2}{*}{$\begin{array}{l}\text { No. of } \\
\text { prescriptions }\end{array}$} & \multirow{2}{*}{ Percentage } \\
\hline & Public Sector (government) & Private Sector & & \\
\hline 1 & Military hospital Rawalpindi & $\begin{array}{l}\text { Ahmad Medical Complex } \\
\text { Rawalpindi }\end{array}$ & $30+30$ & $6.25+6.25$ \\
\hline 2 & Railway hospital Rawalpindi & Safari hospital Rawalpindi & $30+30$ & $6.25+6.25$ \\
\hline 3 & $\begin{array}{l}\text { Pakistan Atomic Energy } \\
\text { Commission General hospital } \\
\text { Islamabad }\end{array}$ & Reliance hospital Islamabad & $30+30$ & $6.25+6.25$ \\
\hline 4 & $\begin{array}{l}\text { Pakistan Institute of Medical } \\
\text { sciences Islamabad }\end{array}$ & $\begin{array}{l}\text { Kulsum International } \\
\text { hospital Islamabad }\end{array}$ & $30+30$ & $6.25+6.25$ \\
\hline 5 & Nescom hospital Islamabad & $\begin{array}{l}\text { Shifa International hospital } \\
\text { Islamabad }\end{array}$ & $30+30$ & $6.25+6.25$ \\
\hline 6 & CDA hospital Islamabad & $\begin{array}{l}\text { Maryam hospital } \\
\text { Rawalpindi }\end{array}$ & $30+30$ & $6.25+6.25$ \\
\hline 7 & DHQ hospital Rawalpindi & Valley hospital Rawalpindi & $30+30$ & $6.25+6.25$ \\
\hline 8 & Polyclinic hospital Islamabad & $\begin{array}{l}\text { Maroof International } \\
\text { hospital Islamabad }\end{array}$ & $30+30$ & $6.25+6.25$ \\
\hline Total & 16 & & $n=480$ & $100 \%$ \\
\hline
\end{tabular}

Table 3: Generic names of all antibiotics prescribed in all hospitals for the treatment of typhoid fever.

\begin{tabular}{|c|l|c|c||}
\hline $\begin{array}{c}\text { S. } \\
\text { No. }\end{array}$ & \multicolumn{1}{|c|}{ Generic name of antibiotics } & $\begin{array}{c}\text { No of } \\
\text { prescriptions } \\
(n=480)\end{array}$ & $\begin{array}{c}\text { Percentages } \\
(\%)\end{array}$ \\
\hline 1 & Ceftriaxone & 66 & 13.75 \\
\hline 2 & Cefixime & 6 & 1.25 \\
\hline 3 & Ciprofloxacin & 145 & 30.21 \\
\hline 4 & Levofloxacin & 6 & 1.25 \\
\hline 5 & Ofloxacin & 17 & 3.54 \\
\hline 6 & Vancomycin & 7 & 1.46 \\
\hline 7 & Clarithromycin & 7 & 1.46 \\
\hline 8 & Ciprofloxacin + Ceftriaxone & 52 & 10.83 \\
\hline 9 & Ciprofloxacin + Cefixime & 47 & 9.79 \\
\hline 10 & Ciprofloxacin + Amoxicillin & 8 & 1.67 \\
\hline 11 & Ciprofloxacin + Piperacillin & 8 & 1.67 \\
\hline 12 & Ciprofloxacin + Piperacillin \& Tazobactam & 10 & 1.67 \\
\hline 13 & Ceftriaxone + Azithromycin & 24 & 2.08 \\
\hline 14 & Ceftriaxone + Cefixime & 11 & 5.0 \\
\hline 15 & Clarithromycin + Cefixime & 48 & 2.29 \\
\hline 16 & $\begin{array}{l}\text { Clarithromycin + Amoxicillin \& Clavulanic } \\
\text { acid }\end{array}$ & 10 & 10 \\
\hline 17 & Cefepime + Cefixime & 480 & $100.0 \%$ \\
\hline & Total & & 2.08 \\
\hline \hline
\end{tabular}


Table 4: Cost ranges of different brands of antibiotics with generic name prescribed in all hospitals.

\begin{tabular}{|c|c|c|c|c|}
\hline $\begin{array}{l}\text { S. } \\
\text { No. }\end{array}$ & $\begin{array}{l}\text { Total cost of } \\
\text { treatment ranges } \\
(\$)\end{array}$ & Brands name with generics & $\begin{array}{l}\text { No of } \\
\text { prescriptions } \\
(n=480)\end{array}$ & $\begin{array}{l}\text { Percentage } \\
\quad(\%)\end{array}$ \\
\hline 1 & $0.98-9.80$ & $\begin{array}{l}\text { - Leflox (Levofloxacin) } \\
\text { - Novidat (Ciprofloxacin) } \\
\text { - Curitol (Ofloxacin) } \\
\text { - Tarivid (Ofloxacin) } \\
\text { - Ciprin (Ciprofloxacin) } \\
\text { - Cipval (Ciprofloxacin) }\end{array}$ & 140 & 29.2 \\
\hline 2 & $9.81-19.60$ & $\begin{array}{l}\text { - Cefspan (Cefixime), } \\
\text { - Cycin (Ciprofloxacin) } \\
\text { - Inj. Cefepime + Cefim (Cefixime) } \\
\text { - Inj. Tanzo (Piperacillin) + Ciproxcin } \\
\text { (Ciprofloxacin) } \\
\text { - Inj. Tazocin (Piperacillin \& Tazobactam) + } \\
\text { Novidat (Ciprofloxacin) } \\
\text { - Ciproxcin (Ciprofloxacin) + Amoxcil } \\
\text { - Cimoxicillin) } \\
\text { - Ciproxcin (Ciprofloxacin) } \\
\text { - Oxidil (Ceftriaxone) + Cefim (Cefixime) } \\
\text { - Inj. Rocephin (Ceftriaxone) + Novidat } \\
\text { (Ciprofloxacin) } \\
\text { - Axcin (Ciprofloxacin) } \\
\text { - Novidat (Ciprofloxacin) } \\
\text { - Ciprofloxacin + Cefim (Cefixime) } \\
\text { - Claritek (Clarithromycin) } \\
\end{array}$ & 144 & 30.0 \\
\hline 3 & $19.61-29.40$ & $\begin{array}{l}\text { - Inj. Rocephin (Ceftriaxone) + Novidat } \\
\text { (Ciprofloxacin) } \\
\text { - Augmentin (Amoxicillin \& Clavulanic acid) + } \\
\text { Klaricid (Clarithromycin) } \\
\text { - Ciproxcin (Ciprofloxacin) + Cefim (Cefixime) } \\
\text { - Novidat (Ciprofloxacin) + Cefspan (Cefixime) } \\
\text { - Ciproxcin, Novidat + Cefspan (Cefixime) }\end{array}$ & 40 & 8.3 \\
\hline 4 & $29.41-39.20$ & $\begin{array}{l}\text { - Cefspan (Cefixime) + Klaricid } \\
\text { - Cefim (Cefixime) + Inj.Novidat (Ciprofloxacin) } \\
\text { - Inj. Oxidil (Ceftriaxone) + Cefim (Cefixime) } \\
\end{array}$ & 35 & 7.3 \\
\hline 5 & $49.01-58.80$ & $\begin{array}{l}\text { - Inj. Cefepime + Cefim (Cefixime) } \\
\text { - Inj. Salxone (Ceftriaxone) }\end{array}$ & 17 & 3.5 \\
\hline 6 & $58.81-68.60$ & $\begin{array}{l}\text { - Inj. Rocephin (Ceftriaxone) + Cefixime } \\
\text { - Inj. Rocephin (Ceftriaxone) } \\
\text { - Inj. Rocephin (Ceftriaxone) + Novidat } \\
\text { (Ciprofloxacin) }\end{array}$ & 40 & 8.3 \\
\hline 7 & $68.61-156.80$ & $\begin{array}{l}\text { - Inj. Rocephin 2g (Ceftriaxone) + Inj. Rocephin } 1 \mathrm{~g} \\
\text { (Ceftriaxone) } \\
\text { - Inj. Rocephin } 2 \mathrm{~g} \text { (Ceftriaxone) } \\
\text { - Inj. Rocephin1g (Ceftriaxone) + Inj. Novidat } \\
\text { (Ciprofloxacin) }\end{array}$ & 57 & 11.9 \\
\hline 8 & $156.81-186.20$ & - Vancomycin & 7 & 1.5 \\
\hline \multicolumn{3}{|r|}{ Total } & 480 & $100.0 \%$ \\
\hline
\end{tabular}

Costs converted into USD ( $\$$ ) in 2014 rate, i.e. ( 1 USD = 101.649 PKR or 0.0098 USD = 1 PKR). 
Novidat) having price range in between \$68.61- 156.80 (PKR 7001 - 16000) was $11.9 \%$ (57/480). While, costs of $1.5 \%$ (7/480) brand was found in the range of \$156.81186.20 (PKR 16001 to 19000).

Comparison of mean public and private costs of treatment due to typhoid fever

Table 5 indicates the relationship between costs of illness of public and private sector hospitals. After coding the costs in term of US dollar and other variables in the SPSS software, minimum cost of treatment, maximum cost, mean cost and standard deviation (SD) for seven and fourteen days treatment in public and private health care hospitals were evaluated. The minimum seven days costs in public sector hospital was found to be \$3.61 (PKR 368) and in private it was $\$ 2.28$ (PKR 233). The maximum costs for seven days treatment in public hospital was noted as $\$ 91.67$ (PKR 9354), while, in private hospitals it was $\$ 77.88$ (PKR 7947). The mean cost for seven days treatment in public and private hospitals were observed to be $\$ 7.20$ (PKR 1436) and $\$ 4.57$ (PKR 2627), respectively. Similarly, the mean cost for fourteen days treatment in public and private hospitals were found to be $\$ 26.66$ (PKR 2720) and \$45.82 (PKR 4676), accordingly. The minimum and maximum costs of illness in public hospitals for fourteen days was noted in the range of $\$ 7.20$ - 183.34 (PKR 735 18708). While, in private hospitals it was found to be $\$ 4.57$ - 155.76 (PKR 466 - 15894). For analysis, Chi-square test $(p \leq 0.05)$ was applied. If $p \leq 0.05$, then, statistically significant differences between the cost of private and public sector hospitals. In the current study, a significant difference $(p \leq 0.000)$ was observed among the costs of brands prescribed in different health care sectors. The average cost of treatment was relatively low in public hospitals as they were prescribing lesser amount of antibiotics in injectable form. While, private hospitals were prescribing multinational brands in the form of intravenous antibiotics which ultimately resulted in increased cost of treatment of typhoid fever in private sectors. This increased in costs in private sector hospitals was due to lesser use of oral antibiotics.

\section{Assessments of different brands of ciprofloxacin $500 \mathrm{mg}$ tablets}

The labeling information of all brands are shown in table 6. Four local and three multinational brands of ciprofloxacin $\mathrm{HCl} 500$ mg tablets were selected and coded as Cipro-1, Cipro-2, Cipro-3, Cipro-4, Cipro-5, Cipro-6 and Cipro-7. Table 7 shows physicochemical evaluation of all brands of ciprofloxacin $\mathrm{HCl}$ $500 \mathrm{mg}$ tablets. The tablets brands were characterized using official ${ }^{14}$ and un-official methods for different pharmaceutical quality parameters such as, weight variation, hardness, friability, disintegration time, assay and dissolution. Hardness of all brands was found satisfactory and the values were felt in between $8.10-11.20 \mathrm{~kg} / \mathrm{cm}^{2}$ (Table 7). Results of weight variation test of all brands were also found within the USP specification of $\pm 5 \%$, as listed in table $7^{22}$. The friability test results of all brands was also found within the limits of $<1 \%$ as specified in pharmacopeia ${ }^{22}$. Similar types of findings were also reported by Saleem et al. $^{23}$ and Shah et $_{\text {al. }}{ }^{24}$.

Table 5: Relationship between costs of illness of public and private sector hospitals.

\begin{tabular}{|c|c|c|c|c|c|c|c|c|c|c|}
\hline \multirow[b]{2}{*}{ Sectors } & \multirow{2}{*}{$\begin{array}{c}\text { No of } \\
\text { prescription } \\
(n=480)\end{array}$} & \multicolumn{4}{|c|}{7 days treatment } & \multicolumn{4}{|c|}{14 days treatment } & \multirow[b]{2}{*}{$\begin{array}{c}\mathrm{P}- \\
\text { value }\end{array}$} \\
\hline & & $\begin{array}{l}\text { Min. } \\
\text { cost }\end{array}$ & $\begin{array}{l}\text { Max. } \\
\text { cost }\end{array}$ & $\begin{array}{c}\text { Mean } \\
\text { Cost } \\
(\$)\end{array}$ & SD & $\begin{array}{l}\text { Min. } \\
\text { cost }\end{array}$ & $\begin{array}{c}\text { Max. } \\
\text { cost }\end{array}$ & $\begin{array}{c}\text { Mean } \\
\text { Cost } \\
(\$)\end{array}$ & SD & \\
\hline Public & 240 & 3.61 & 91.67 & 14.07 & 20.62 & 7.20 & 183.34 & 26.66 & 40.74 & \multirow{2}{*}{0.000} \\
\hline Private & 240 & 2.28 & 77.88 & 25.74 & 22.01 & 4.57 & 155.76 & 45.82 & 41.10 & \\
\hline
\end{tabular}

Chi-Square test $(p \leq 0.05)$ : $\mathrm{SD}=$ standard deviation; $\$=\mathrm{US}$ dollar. 
Table 6: Labelling information of all brands of ciprofloxacin $(500 \mathrm{mg})$ tablets.

\begin{tabular}{||c|c|c|c|c||}
\hline $\begin{array}{c}\text { Brand } \\
\text { Code }\end{array}$ & Company & Batch Number & Expiry Date & $\begin{array}{c}\text { Retail price per } \\
10 \text { tablets }(\$)\end{array}$ \\
\hline Cipro-1 & Multinational & KHO 2282 & $12 / 2019$ & $\$ 4.95$ \\
\hline Cipro-2 & Local & $004 \mathrm{~A}$ & $12 / 2019$ & $\$ 2.76$ \\
\hline Cipro-3 & Local & 6720 & $03 / 2018$ & $\$ 2.89$ \\
\hline Cipro-4 & Local & 239 & $01 / 2019$ & $\$ 2.16$ \\
\hline Cipro-5 & Multinational & BDCWAH & $12 / 2018$ & $\$ 2.11$ \\
\hline Cipro-6 & Multinational & J0466 & $12 / 2019$ & $\$ 2.45$ \\
\hline Cipro-7 & Local & 002 & $11 / 2019$ & $\$ 3.78$ \\
\hline
\end{tabular}

Table 7: Physicochemical evaluation of all brands of ciprofloxacin $\mathrm{HCl} 500 \mathrm{mg}$ tablets.

\begin{tabular}{|c|c|c|c|c|c|}
\hline $\begin{array}{c}\text { Brand } \\
\text { code }\end{array}$ & $\begin{array}{c}\text { Weight variation } \\
(\mathrm{mg})\end{array}$ & $\begin{array}{c}\text { Hardness }^{* * *} \\
\left(\mathrm{~kg} / \mathrm{cm}^{2}\right)\end{array}$ & $\begin{array}{c}\text { Friability }^{* * *} \\
(\%)\end{array}$ & $\begin{array}{c}\text { Disintegration }^{* * * *}(\mathrm{~min}) \\
\text { Time }^{* * *}\end{array}$ & $\begin{array}{c}\text { Assay }^{*} \\
(\%)\end{array}$ \\
\hline Cipro-1 & $784.3 \pm 7.82$ & $11.20 \pm 2.20$ & $0.31 \pm 0.09$ & 1.8 & $98.60 \pm 0.75$ \\
\hline Cipro-2 & $733.7 \pm 6.78$ & $8.10 \pm 2.55$ & $0.11 \pm 0.11$ & 1.1 & $96.8 \pm 0.54$ \\
\hline Cipro-3 & $894.7 \pm 7.87$ & $8.70 \pm 4.12$ & $0.31 \pm 0.21$ & 7.5 & $97.5 \pm 1.06$ \\
\hline Cipro-4 & $818.5 \pm 6.05$ & $9.50 \pm 1.56$ & $0.18 \pm 0.36$ & 3.3 & $94.8 \pm 1.32$ \\
\hline Cipro-5 & $670.9 \pm 5.11$ & $10.6 \pm 2.07$ & $0.20 \pm 1.21$ & 5.7 & $101.7 \pm 0.99$ \\
\hline Cipro-6 & $773.5 \pm 6.24$ & $9.80 \pm 1.17$ & $0.28 \pm 1.21$ & 2.6 & $101.5 \pm 0.99$ \\
\hline Cipro-7 & $726.3 \pm 7.33$ & $10.25 \pm 2.21$ & $0.34 \pm 1.21$ & 3.8 & $97.8 \pm 0.99$ \\
\hline
\end{tabular}

All values are expressed as mean $\pm \mathrm{SD} ; * n=10 ; * * n=20 ; * * * n=6$.

\section{Disintegration test}

Disintegration test directly correlate how much the tablet will take to disintegrate and to absorb inside the body. The disintegration time of all brands was found in the range of 1.1-7.5 min (Table 7), indicating that all brands complying the USP acceptance limits of not more than $30 \mathrm{~min}^{22}$. Results showed that Cipro3 took more time (7.5 min), while, Cipro- 2 took least time $(1.1 \mathrm{~min})$ to disintegrate. This slight variation may be due to differences in their formulation composition.

\section{Assay of Ciprofloxacin tablets}

Assay of Ciprofloxacin $500 \mathrm{mg}$ tablets was performed using HPLC method as stated in the official Pharmacopeia ${ }^{16}$. The assay results of all brands were found in the range of
$96.8 \pm 0.54$ to $101.7 \pm 0.99 \%$, as illustrated in table 7 . The results were observed within the pharmacopoeial limits of $90-110^{16}$.

\section{In-vitro drug release studies}

Multiple point dissolution study was performed for comparison of all the seven brands by using the USP dissolution type II apparatus at $50 \mathrm{rpm}$. The samples were withdrawn at a time interval of 5, 10, 20 and 30 min. The dissolution studies showed satisfactory results of all brands and complied the USP specification of not less than $80 \%$ at $30 \mathrm{~min}$. The results of all three brands were in the range of 88.30 to $97.50 \%$ as shown in table 8. Previously, moxifloxacin $400 \mathrm{mg}$ tablet brands were evaluated and reported drug release in the range of $93.11-96.25 \%{ }^{24}$. 
Table 8: Dissolution profile of all brands of Ciprofloxacin $500 \mathrm{mg}$ tablet and similarity factor $\left(f_{2}\right)$.

\begin{tabular}{|c|c|c|c|c|c|c|}
\hline \multirow{2}{*}{$\begin{array}{l}\text { Brand } \\
\text { Code }\end{array}$} & \multicolumn{4}{|c|}{$\begin{array}{c}\text { Mean dissolution rate at different time interval } \\
(\%)\end{array}$} & \multirow{2}{*}{$\begin{array}{l}\text { USP } \\
\text { Limit }\end{array}$} & \multirow{2}{*}{$\begin{array}{l}\text { Similarity factor }\left(f_{2}\right) \text { values } \\
\qquad(\%)\end{array}$} \\
\hline & At $5 \mathrm{~min}$ & At $10 \mathrm{~min}$ & At $20 \mathrm{~min}$ & At $30 \mathrm{~min}$ & & \\
\hline Cipro-1 & 75.66 & 85.82 & 94.76 & 94.7 & \multirow{7}{*}{ 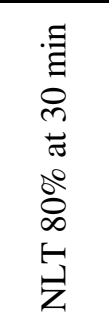 } & Reference \\
\hline Cipro-2 & 70.21 & 83.50 & 90.37 & 92.8 & & Cipro-1 \& Cipro-2= 62.56 \\
\hline Cipro-3 & 67.41 & 74.04 & 83.55 & 88.6 & & Cipro-1 \& Cipro-3= 46.51 \\
\hline Cipro-4 & 61.52 & 77.20 & 89.5 & 91.4 & & Cipro-1 \& Cipro-4= 48.57 \\
\hline Cipro-5 & 75.66 & 88.82 & 92.76 & 97.5 & & Cipro-1 \& Cipro-5= 80.73 \\
\hline Cipro-6 & 66.48 & 80.20 & 92.54 & 93.9 & & Cipro-1 \& Cipro-6= 56.06 \\
\hline Cipro-7 & 69.56 & 73.11 & 82.43 & 88.3 & & Cipro-1 \& Cipro-7= 45.89 \\
\hline
\end{tabular}

\section{Drug release profile comparison (Similarity Factor $f_{2}$ Value) \\ The similarity between dissolution} profiles of other six brands as compare to reference product (Cipro-1) was assessed by applying similarity factor $\left(f_{2}\right)$ using DD Solver (an Excel add-in software) ${ }^{17}$. The observed $f_{2}$ values of brand Cipro-2, Cipro-5 and Cipro-6 were found within the range of $56.06-80.73 \%$, which indicated that there were similarity in the release profile of these three brands of Ciprofloxacin $500 \mathrm{mg}$ tablets when compared with reference brand. Similarly, the $f_{2}$ values of brand Cipro-3, Cipro-4 and Cipro-7 were found within the range of $45.89-48.57 \%$, indicating dissimilarity between these brands as shown in table 8. According to the FDA guidelines, if the values of $f_{2}$ are within the range of $50-100 \%$, it indicates equivalence and if the values are less than $50 \%$, then, there is no similarity between two dissolution profiles ${ }^{18}$.

\section{Conclusion}

A retrospective study was designed to assess the cost of treatment and to evaluate which sectors (public or private) of health care of Pakistan is providing cost effective treatment for typhoid fever. Quantitative method was used for the purpose of data collection so that a cost effective and cost expensive treatment can be estimated. The quality parameters of seven Ciprofloxacin 500 brands were also evaluated such as weight variation, Hardness, friability, disintegration time, in-vitro dissolution and assay and results were found within the acceptance ranges of USP, with no significant difference in their results. Hence, the outcomes of the study revealed that all brands possess good pharmaceutical qualities. Therefore, findings of the current study revealed that prescribing practice in both public and private sector hospitals was in accordance with the standard guidelines treatment of WHO for typhoid fever. The average treatment cost for typhoid was greater in private tertiary health care sector as compared to public tertiary health care sector. It can also be concluded that low cost brand of Ciprofloxacin 500 brands can be prescribed and interchanged rather than costly brand.

\section{Acknowledgements}

Authors are thankful to the Department of Pharmaceutics, Riphah Institute of Pharmaceutical Sciences, Islamabad, Pakistan for providing data facilities.

\section{Conflict of interest statement}

Authors declared no conflict of interests.

\section{Funding}

For this projects no funding was available.

\section{REFERENCES}

1- M. Raffatellu, R. P. Wilson, S. E. Winter and A. J. Baumler, "Clinical pathogenesis of typhoid fever", The Journal of Infection in Developing Countries, 2, 260-266 (2008).

2- J. A. Crump, S. P. Luby and E. D. Mintz, "The global burden of typhoid fever", Bulletin of the World Health Organization, 82, 346 (2004).

3- R. L. Ochiai, C. J. Acosta, M. DanovaroHolliday, D. Baiqing, S. K. Bhattacharya, M. D. Agtini, Z. A. Bhutta, D. G. Canh, M. Ali and S. Shin, "A study of typhoid 
fever in five Asian countries: Disease burden and implications for controls", ibid., 86, 260 (2008).

4- A. Owais, S. Sultana, U. Zaman, A. Rizvi and A. K. Zaidi, "Incidence of typhoid bacteremia in infants and young children in southern coastal Pakistan", The Pediatric Infectious Disease Journal, 29, 1035 (2010).

5- T. E. Woodward, J. E. Smadel, H. L. LEY, R. Green and D. Mankikar, "Preliminary report on the beneficial effect of chloromycetin in the treatment of typhoid fever", Annals of Internal Medicine, 29, 131 (1948).

6- S. Mirza, N. Beechmg and C. Hart, "Multi-drug resistant typhoid: A global problem", Journal of Medical Microbiology, 44, 317 (1996).

7- F. E. Abdullah, F. Haider, K. Fatima, S. Irfan and M. S. Iqbal, "Enteric fever in Karachi: Current antibiotic susceptibility of Salmonellae isolates", Journal of the College of Physicians and Surgeons Pakistan, 22, 147 (2012).

8- A. Kothari, A. Pruthi and T. D. Chugh, "The burden of enteric fever", The Journal of Infection in Developing Countries, 2, 253 (2008).

9- W. H. Organization, In: "Guidelines for the Management of Typhoid Fever" (2011).

10- N. Ngwuluka, K. Lawal, P. Olorunfemi and N. Ochekpe", "Post-market in-vitro bioequivalence study of six brands of ciprofloxacin tablets/caplets in Jos, Nigeria", Scientific Research and Essays, 4, 298 (2009).

11- D. Sur, S. Chatterjee, A. Riewpaiboon, B. Manna, S. Kanungo and S. K. Bhattacharya, "Treatment cost for typhoid fever at two hospitals in Kolkata, India", Journal of Health, Population, and Nutrition, 27, 725 (2009).

12- UN-Habitat, "Cities and Climate Change Initiative, A Bridged Report IslamabadPakistan, Climate Change Vulnerability Assessment", United Nations Human Settlements Programme (UN-Habitat) Islamabad (2014).
13- PharmaGuide, "Hand Book Published Annually Providing Essential Prescribing and Trade Information", 25 ${ }^{\text {th }}$ Edn. (2018).

14- USP35-NF30, "The United States Pharmacopeial Convention", USA (2013).

15- F. Qamar, S. Alam, S. Naveed and H. Ali, "Quality assessment and dissolution profile comparison studies on naproxen tablets available in Karachi", RADS-J. Pharm. Pharm. Sci., 5, 32 (2017).

16- USP/NF, "The United States Pharmacopoeia 36/National Formulary", 31 (2013).

17- Y. Zhang, M. Huo, J. Zhou, A. Zou, W. Li, C. Yao and S. Xie, "DDSolver: An add-in program for modeling and comparison of drug dissolution profiles", The AAPS Journal, 12, 263 (2010).

18- P. Costa and J. M. S. Lobo, "Modeling and comparison of dissolution profiles", European Journal of Pharmaceutical Sciences, 13, 123 (2001).

19- E. Pagano, M. Brunetti, F. Tediosi and L. Garattini, "Costs of diabetes", Pharmacoeconomics, 15, 583 (1999).

20- S. Lerman, D. Shepard and R. Cash, "Treatment of diarrhoea in Indonesian children: What it costs and who pays for it", The Lancet, 326, 651 (1985).

21- N. H. Punjabi, "Cost evaluation of typhoid fever in Indonesia", Medical Journal of Indonesia, 7, 90-93 (1998).

22- UPS32/NF27, "The United States Pharmacopeial Convention", USA, 262 (2009).

23- A. Saleem, M. I. Nasiri, K. Zaheer, S. Anwer, T. Ali, H. Sarwar and S. S. Naqvi, "Comparative pharmaceutical equivalence studies of sofosbuvir $400 \mathrm{mg}$ tablets available in Pakistani market", Latin American Journal of Pharmacy, 37, 2476 (2018).

24- M. R. Shah, M. I. Nasiri, S. Anwer, T. Ali, K. Zaheer, K. Ahmed and M. U. Saleem, "Pharmaceutical quality assessment of different brands of moxifloxacin $400 \mathrm{mg}$ tablets available in Pakistan", RADS Journal of Pharmacy and Pharmaceutical Sciences, 7, 2 (2019). 


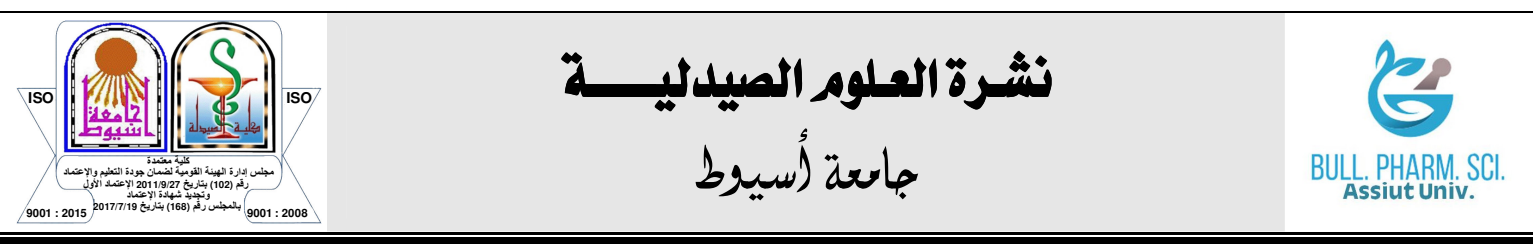

\section{تحليل تكلفة مرض حمى التيفوئيد في مستشفيات الرعاية المتخصصة والتقيبم}

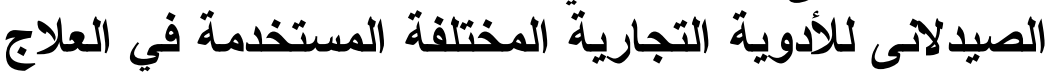

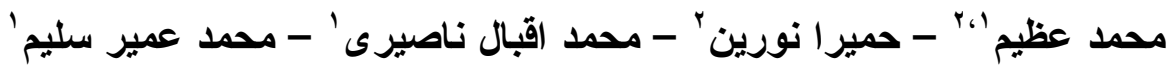
'قسم الصيدلانيات ،معهد حمدارد للعلوم الصيدلية ، جامعة حمدارد ، إسلام أباد ، باكستان

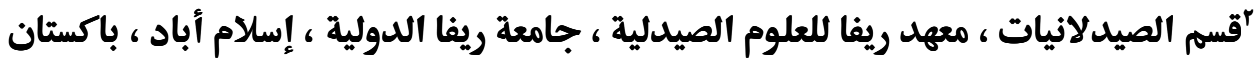

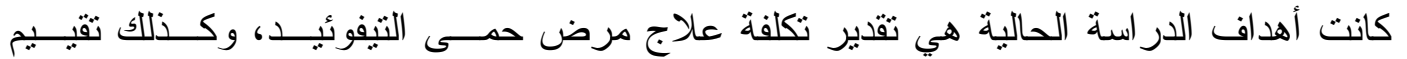

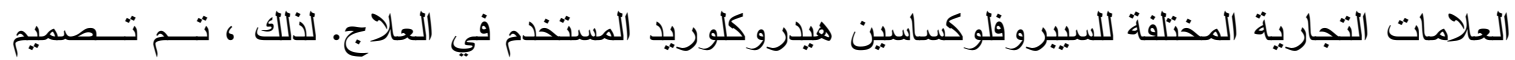

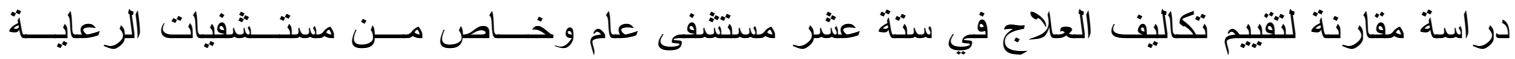

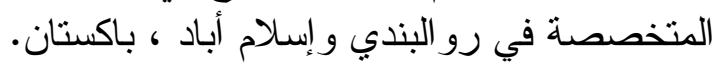

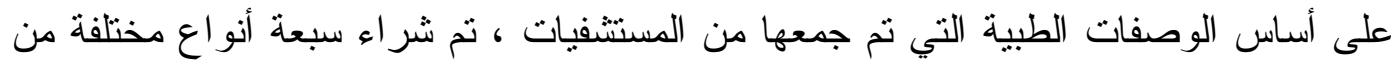

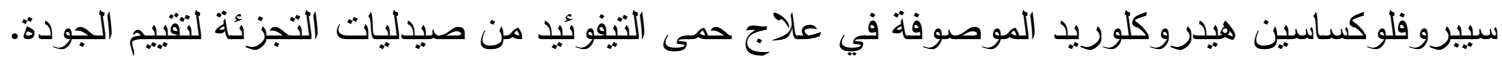

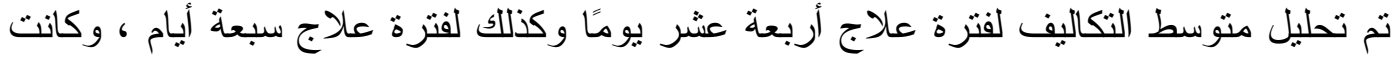

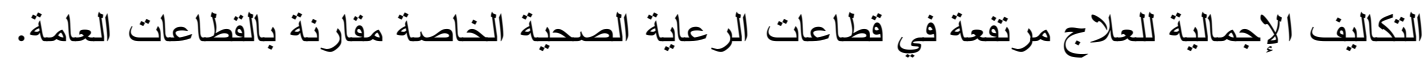

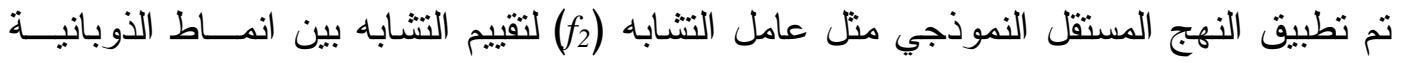

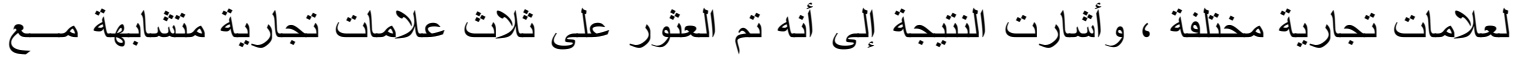

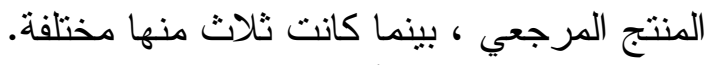

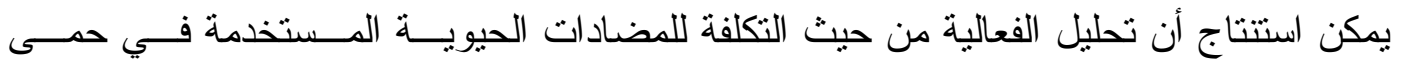

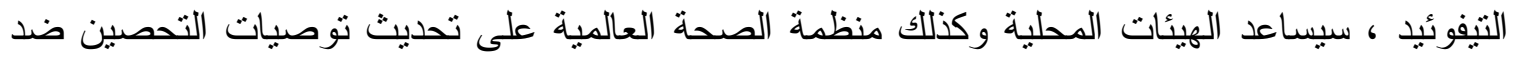

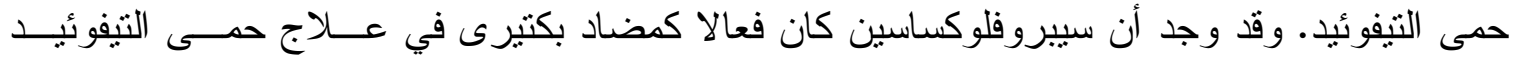

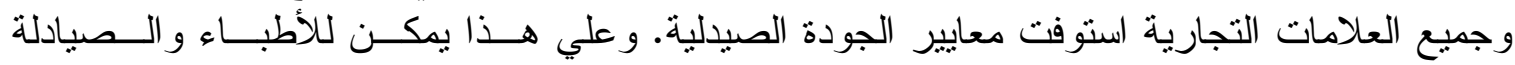
و المرضى اختيار العلامة التجارية الأكثر ملاعمة لعلاج حمى التيفوئيد. 